\title{
An Elevated Dietary Cysteine to Methionine Ratio Does Not Impact on Dietary Methionine Efficiency and the Derived Optimal Methionine to Lysine Ratio in Diets for Meat Type Chicken
}

\author{
Daulat Rehman Khan, Christian Wecke, Frank Liebert \\ Department of Animal Sciences, Division Animal Nutrition Physiology, University of Goettingen, Goettingen, \\ Germany \\ Email: flieber@gwdg.de
}

Received 6 August 2015; accepted 13 October 2015; published 16 October 2015

Copyright (C) 2015 by authors and Scientific Research Publishing Inc.

This work is licensed under the Creative Commons Attribution International License (CC BY). http://creativecommons.org/licenses/by/4.0/

(c) (i) Open Access

\begin{abstract}
Optimal dietary methionine (Met) to lysine (Lys) ratio in presence of elevated dietary cysteine (Cys) levels was derived for meat type growing chicken. Twelve averaged weighed Ross 308 birds (each $50 \%$ of male and female per dietary treatment) were utilized in $\mathrm{N}$ balance trials. During starter (d10 - 20) and grower period (d25 - 35) five dietary treatments were used. Diets based on uniform mixtures of maize, wheat, soybean meal, potato protein and fish meal were supplemented with crystalline amino acids (AA). In diets $1-3$, the dietary Cys to Met ratio was set as 85, 95 and 105 to 100, respectively. Diet 4, at a Cys to Met ratio of 105 to 100, was additionally supplemented with betaine (BET) as methyl group donor. Diets 1 - 4 were limiting in Met, diet 5 without $\mathrm{L}$-Lys $\cdot \mathbf{H C l}$ addition was limiting in Lys. Individual $\mathrm{N}$-balance data per treatment were utilized for assessing protein quality and efficiency of dietary Met (Diets 1 - 4) or Lys (Diet 5) based on "Goettingen approach". Elevated dietary Cys supply and supplemented BET failed to improve both dietary protein quality and Met efficiency. The established optimal Met to Lys ratio was on average 34 to 100 for growing chicken during starter and grower period, respectively.
\end{abstract}

\section{Keywords}

Growing Chicken, N Utilization Model, Amino Acid Efficiency, Methionine to Lysine Ratio, Cysteine, Betaine 


\section{Introduction}

In a series of experiments the application of ideal protein concepts provided a considerable impact on efficacy of protein utilization, growth performance and carcass yields in growing chicken [1]-[8] and recommendations are available about the expected ideal amino acid ratio (IAAR) in diets of meat type chicken as summarized by Wecke and Liebert [8]. Currently, there are indications that optimal ratios of individual AAs related to lysine might change depending on age period, feed protein source and dietary AA efficiency [7]-[11].

In addition to be part of body protein synthesis, sulfur containing amino acids (SAA) play a very important role in different metabolic processes in growing animals [12] [13]. Consequently, recommended optimal SAA to Lys ratios are currently not conclusive. Opposite to starter chicken with a SAA to Lys ratio between 71 and 72 to 100 [14]-[16], during grower period ratios between 69 and 75 to 100 are reported [14]-[19]. However, higher proportions of minimum 77 [20] or 82 [21] of total SAA as related to Lys were proposed, especially when feed efficiency and carcass yield were the reference criterion. Even the recommendations of both NRC [22] and GRRS [23] varied from 71 to 100 vs. 82 to 100 for starter and 87 to 100 vs. 72 to 100 for grower chicken, respectively. Based on 24 reports, Wecke and Liebert [8] summarized $74 \pm 2$ to 100 as optimal SAA to Lys ratio, whereby $40 \pm 4$ to 100 counted as optimal for Met to Lys. Actual studies assessing these IAARs and taking into account varying dietary Cys supply are scarce and inconclusive. It is indicated by Dilger and Baker [24] and observations of Liebert et al. [25] that dietary Cys concentration has influence on efficiency of Met utilization in chicks. In addition, the question arises if Met efficiency could be further improved by minimizing its metabolic utilization as donor of methyl groups. Several betaine (BET) supplementation studies provide support for this assumption [26]-[30].

Accordingly, the current experiments aimed to measure the dietary Met efficiency both at graded dietary Cys:Met ratios and supplemented BET to re-evaluate the optimal Met:Lys ratio for growing chicken based on further applications of the "Goettingen approach" [31].

\section{Materials and Methods}

The experiments were conducted at the Division Animal Nutrition Physiology of Georg-August-University Goettingen, approved by the Animal Welfare Law Committee of Lower Saxony, Germany.

\subsection{Stock and Husbandry}

One day old growing meat type chicken (Ross 308) were obtained from a commercial hatchery and kept on wood shavings in a floor pen under standard feeding and management conditions up to the start of experiments. Sixty (starter period, d10 - 20) and sixty (grower period, d25 - 35) averaged weighed birds (males and females mixed 1:1) were utilized in $\mathrm{N}$ balance trials. During balance experiments, the birds were individually housed in metabolic cages but adapted to the floor size for starter $(25 \times 30 \mathrm{~cm})$ and grower period $(80 \times 80 \mathrm{~cm})$, respectively. Each metabolic cage was equipped with a wire floor, individual feeder and automatic drinking system. Housing temperature was maintained at $30^{\circ} \mathrm{C}-27^{\circ} \mathrm{C}$ within the starter and at $24^{\circ} \mathrm{C}-20^{\circ} \mathrm{C}$ in the grower period. Monochromatic (red) light was provided for 23 hours daily.

\subsection{Diets and Feeding}

Birds were randomly allotted to 5 pelleted diets both during starter and grower period with 6 replicates per diet and gender. Diets were formulated with the objective to ensure a constant ratio of maize, wheat, soybean meal, potato protein and fish meal, respectively (Table 1). According to age dependent requirements, the energy and CP content of the experimental diets was adapted. Diet 1 provided the basal ratio with Cys supply at $46 \%$ of the SAA which was gradually enhanced up to $51 \%$ (diet 3). At this level of Cys supply, $1 \mathrm{~g} / \mathrm{kg}$ BET was added (diet 4). Diet 5 was formulated to create Lys as the limiting AA by deletion of L-Lys· HCl. Diet 5 was needed to measure the Lys efficiency as reference AA for further conclusions about the optimal Met:Lys ratio. Analysed composition of all experimental diets is summarized in Table 2.

\subsection{Collection and Sampling}

$\mathrm{N}$ balance studies were divided into an adaptation period (5 d) and 2 consecutive collecting periods (each $5 \mathrm{~d}$ ) 
Table 1. Composition of experimental diets (g/kg).

\begin{tabular}{|c|c|c|c|c|c|c|c|c|c|c|}
\hline \multirow[b]{2}{*}{ Diet } & \multicolumn{5}{|c|}{ Starter period $(\mathrm{d} 10-20)$} & \multicolumn{5}{|c|}{ Grower period (d25 - 35) } \\
\hline & 1 & 2 & 3 & 4 & 5 & 1 & 2 & 3 & 4 & 5 \\
\hline Cys:Met & $85: 100$ & $95: 100$ & $105: 100$ & $105: 100^{3}$ & $95: 100^{4}$ & $85: 100$ & $95: 100$ & $105: 100$ & $105: 100^{3}$ & $95: 100^{4}$ \\
\hline Maize & 560 & 560 & 560 & 560 & 560 & 516.9 & 516.9 & 516.9 & 516.9 & 516.9 \\
\hline Wheat & 70 & 70 & 70 & 70 & 70 & 64.6 & 64.6 & 64.6 & 64.6 & 64.6 \\
\hline Soy protein concentrate & 180 & 180 & 180 & 180 & 180 & 166.1 & 166.1 & 166.1 & 166.1 & 166.1 \\
\hline Fish meal & 60 & 60 & 60 & 60 & 60 & 55.4 & 55.4 & 55.4 & 55.4 & 55.4 \\
\hline Potato protein & 50 & 50 & 50 & 50 & 50 & 46.2 & 46.2 & 46.2 & 46.2 & 46.2 \\
\hline Soybean oil & 30 & 30 & 30 & 30 & 30 & 32.0 & 32.0 & 32.0 & 32.0 & 32.0 \\
\hline Premix ${ }^{1}$ & 10 & 10 & 10 & 10 & 10 & 10.0 & 10.0 & 10.0 & 10.0 & 10.0 \\
\hline Wheat starch & 16.5 & 16.0 & 15.4 & 14.4 & 15.5 & 90.2 & 89.6 & 89.2 & 88.2 & 89.2 \\
\hline DCP & 9.0 & 9.0 & 9.0 & 9.0 & 9.0 & 8.0 & 8.0 & 8.0 & 8.0 & 8.0 \\
\hline $\mathrm{CaCO}_{3}$ & 7.8 & 7.8 & 7.8 & 7.8 & 7.8 & 5.0 & 5.0 & 5.0 & 5.0 & 5.0 \\
\hline $\mathrm{NaCl}$ & 1.6 & 1.6 & 1.6 & 1.6 & 1.6 & 1.0 & 1.0 & 1.0 & 1.0 & 1.0 \\
\hline L-Lysine $\cdot \mathrm{HCl}$ & 2.67 & 2.67 & 2.67 & 2.67 & - & 2.46 & 2.46 & 2.46 & 2.46 & - \\
\hline L-Arginine & 2.24 & 2.24 & 2.24 & 2.24 & 2.24 & 2.07 & 2.07 & 2.07 & 2.07 & 2.07 \\
\hline L-Cystine $\cdot \mathrm{HCl} \cdot \mathrm{H}_{2} \mathrm{O}$ & - & 0.55 & 1.08 & 1.08 & 2.36 & - & 0.51 & 1.00 & 1.00 & 2.18 \\
\hline L-Tryptophan & 0.08 & 0.08 & 0.08 & 0.08 & 0.08 & 0.07 & 0.07 & 0.07 & 0.07 & 0.07 \\
\hline L-Valine & 0.09 & 0.09 & 0.09 & 0.09 & 0.09 & 0.08 & 0.08 & 0.08 & 0.08 & 0.08 \\
\hline Betaine $^{2}$ & - & - & - & 1.0 & - & - & - & - & 1.0 & - \\
\hline DL-Methionine & - & - & - & - & 1.33 & - & - & - & - & 1.23 \\
\hline
\end{tabular}

${ }^{1}$ Provided (per kilogram of diet): vitamin A, 12,000 IU; vitamin D3, $3500 \mathrm{IU}$; vitamin E, 40 mg; thiamin, 2.5 mg; riboflavin, 8.0 mg; vitamin B6, 6.0

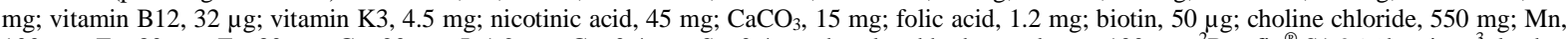
$100 \mathrm{mg}$; Zn, $80 \mathrm{mg}$; Fe, $30 \mathrm{mg}$; Cu, $20 \mathrm{mg}$; I, $1.2 \mathrm{mg}$; Co, $0.4 \mathrm{mg}$; Se, $0.4 \mathrm{mg}$; butylated hydroxytoluene, $100 \mathrm{mg}$. ${ }^{2}$ Betafin ${ }^{\circledR} \mathrm{S} 1: 96 \%$ betaine; ${ }^{3}$ plus betaine $\left(1 \mathrm{~g} / \mathrm{kg}\right.$ diet); ${ }^{4}$ diet without supplemented L-lysine· $\mathrm{HCl}$ (Lys limiting diet).

Table 2. Analysed nutrient content of experimental diets.

\begin{tabular}{|c|c|c|c|c|c|c|c|c|c|c|}
\hline \multirow[b]{2}{*}{ Diet } & \multicolumn{5}{|c|}{ Starter period (d10 - 20) } & \multicolumn{5}{|c|}{ Grower period (d25 - 35) } \\
\hline & 1 & 2 & 3 & 4 & 5 & 1 & 2 & 3 & 4 & 5 \\
\hline Cys: Met & $85: 100$ & $95: 100$ & $105: 100$ & $105: 100^{1}$ & $95: 100^{2}$ & $85: 100$ & $95: 100$ & $105: 100$ & $105: 100^{1}$ & $95: 100^{2}$ \\
\hline \multicolumn{11}{|c|}{ Crude nutrients (g/kg dry matter) } \\
\hline Crude protein & 239.4 & 239.7 & 240.0 & 240.2 & 238.7 & 219.8 & 220.1 & 220.4 & 220.6 & 219.2 \\
\hline Ether extract & 66.7 & 66.6 & 66.4 & 66.5 & 66.5 & 67.7 & 67.6 & 67.6 & 67.4 & 67.3 \\
\hline Crude fiber & 29.3 & 29.1 & 29.3 & 29.2 & 29.3 & 28.0 & 27.9 & 28.0 & 27.9 & 27.8 \\
\hline Crude ash & 63.4 & 63.4 & 63.2 & 63.3 & 63.1 & 57.5 & 57.3 & 57.4 & 57.2 & 57.1 \\
\hline $\mathrm{N}$-free extract & 601.2 & 601.2 & 601.1 & 600.8 & 602.4 & 627.0 & 627.1 & 626.6 & 626.9 & 628.6 \\
\hline $\operatorname{AMEn}(\mathrm{MJ} / \mathrm{kg} \mathrm{DM})^{3}$ & 14.35 & 14.35 & 14.34 & 14.36 & 14.32 & 14.73 & 14.72 & 14.72 & 14.71 & 14.66 \\
\hline \multicolumn{11}{|l|}{ Amino acids (g/16gN) } \\
\hline Lys & 6.15 & 6.14 & 6.14 & 6.14 & 5.18 & 6.15 & 6.14 & 6.14 & 6.14 & 5.18 \\
\hline Met & 1.72 & 1.72 & 1.71 & 1.71 & 2.34 & 1.72 & 1.72 & 1.71 & 1.71 & 2.34 \\
\hline Met + Cys & 3.17 & 3.34 & 3.51 & 3.51 & 4.56 & 3.17 & 3.34 & 3.51 & 3.51 & 4.56 \\
\hline Thr & 3.97 & 3.96 & 3.96 & 3.96 & 3.98 & 3.97 & 3.96 & 3.96 & 3.96 & 3.98 \\
\hline $\operatorname{Trp}$ & 1.11 & 1.10 & 1.10 & 1.10 & 1.11 & 1.11 & 1.10 & 1.10 & 1.10 & 1.11 \\
\hline Arg & 6.46 & 6.45 & 6.44 & 6.44 & 6.47 & 6.46 & 6.45 & 6.44 & 6.44 & 6.47 \\
\hline Leu & 8.61 & 8.60 & 8.59 & 8.59 & 8.64 & 8.61 & 8.60 & 8.59 & 8.59 & 8.64 \\
\hline Ile & 3.75 & 3.75 & 3.74 & 3.74 & 3.76 & 3.75 & 3.74 & 3.74 & 3.74 & 3.76 \\
\hline Val & 4.30 & 4.30 & 4.29 & 4.29 & 4.32 & 4.30 & 4.30 & 4.29 & 4.29 & 4.32 \\
\hline
\end{tabular}

${ }^{1}$ Plus betaine ( $1 \mathrm{~g} / \mathrm{kg}$ diet); ${ }^{2}$ without supplemented L-lysine $\mathrm{HCl}$ (Lys limiting diet); ${ }^{3}$ Nitrogen corrected apparent metabolizable energy, calculated according to WPSA [32]. 
according to the procedure of Pastor et al. [7]. At start of the adaptation period, the feed supply was ad libitum to estimate the proper level of individual feed intake under housing conditions in metabolic cages. The individual feed supply was kept constant from day 3 of the adaptation period, slightly adapted during the first two days of the collecting periods and kept constant again up to the end of the collecting period. Excreta collection was conducted 2 times a day to prevent ammonia losses from un-acidified excreta. Excreta samples were immediately frozen and stored at $-20^{\circ} \mathrm{C}$ until further analysis.

\subsection{Laboratory Analysis}

Dietary ingredients, experimental diets and excreta were analyzed according to the German standards [33]. The $\mathrm{N}$ content was quantified due to the Dumas method (Leco ${ }^{\circledR}$ LP-2000, Leco Instrument GmbH, Kirchheim, Germany) and CP was calculated with factor 6.25. AA composition of the protein sources were analyzed by ion-exchange chromatography (Biochrom ${ }^{\circledR}$ 30, Biochrom Ltd. Cambridge, England) following acid hydrolysis without and with an oxidation step for quantitative determination of SAA. According to the German standards, ether extract was analyzed following $\mathrm{HCl}$ hydrolysis of the feed samples.

\subsection{Model Application and Statistics}

The data analysis by "Goettingen approach" utilized principles of an exponential $\mathrm{N}$ utilization model as currently summarized by Liebert [31]. The approach makes use of following basic equations:

$$
\begin{gathered}
\mathrm{NR}=\mathrm{NR}_{\max } \mathrm{T}\left(1-\mathrm{e}^{-b \cdot \mathrm{NI}}\right) \\
\mathrm{ND}=\mathrm{NR}_{\max } \mathrm{T}\left(1-\mathrm{e}^{-b \cdot \mathrm{NI}}\right)-\mathrm{NMR}
\end{gathered}
$$

where $\mathrm{NR}=$ daily $\mathrm{N}$ retention $\left(\mathrm{ND}+\mathrm{NMR} ; \mathrm{mg} / \mathrm{BW}_{\mathrm{kg}}{ }^{0.67}\right) ; \mathrm{NR}_{\max } \mathrm{T}=$ daily theoretical maximum for $\mathrm{NR}$ $\left(\mathrm{mg} / \mathrm{BW}_{\mathrm{kg}}{ }^{0.67}\right) ; \mathrm{ND}=$ daily $\mathrm{N}$ deposition $\left(\mathrm{mg} / \mathrm{BW}_{\mathrm{kg}}{ }^{0.67}\right) ; \mathrm{NMR}=$ daily nitrogen maintenance requirement $\left(\mathrm{mg} / \mathrm{BW}_{\mathrm{kg}}{ }^{0.67}\right) ; \mathrm{NI}=$ daily $\mathrm{N}$ intake $\left(\mathrm{mg} / \mathrm{BW}_{\mathrm{kg}}{ }^{0.67}\right) ; b=$ slope of the $\mathrm{N}$ retention curve (indicating the feed protein quality independent of NI); e = basic number of natural logarithm (ln).

According to Samadi and Liebert [9], this study utilized a mean value of NMR (221 $\left.\mathrm{mg} / \mathrm{BW}_{\mathrm{kg}}{ }^{0.67}\right)$ for both experimental periods. In addition, an averaged $\mathrm{NR}_{\max } \mathrm{T}$ for the starter $\left(3884 \mathrm{mg} / \mathrm{BW}_{\mathrm{kg}}{ }^{0.67}\right.$ ) and the grower period $\left(2972 \mathrm{mg} / \mathrm{BW}_{\mathrm{kg}}{ }^{0.67}\right)$ was applied as model parameter. Based on individual NI and NR data, the protein quality parameter $b$ was calculated by Equation (3):

$$
b=\left[\operatorname{lnNR}_{\max } \mathrm{T}-\ln \left(\mathrm{NR}_{\max } \mathrm{T}-\mathrm{NR}\right)\right] / \mathrm{NI}
$$

The model parameter $b$ linearly depends on the concentration $(c ; \mathrm{g} / 16 \mathrm{gN})$ of the limiting AA (LAA) in the corresponding feed protein and the slope $\left(b c^{-1}\right)$ is utilized as expression of AA efficiency as reported earlier [9] [31] [34]. The AA efficiency $\left(b c^{-1}\right)$ summarizes both digestibility and post absorptive utilization of the LAA under study. The order of observed $b c^{-1}$ data from individual AA is indirectly correlated to the physiological requirement per unit protein deposition. According to [9], the reciprocal relationship between Lys efficiency (as reference AA) and the observed efficiency of the individual LAA under study is utilized to derive optimal dietary AA ratios (IAAR) as currently reported [7] [8]:

$$
\text { IAAR }=b c_{\text {LYS }}{ }^{-1}: b c_{\mathrm{LAA}^{-1}}
$$

Statistical analyses run with SPSS software package (Version 22 for Windows; SPSS Inc., IBM, Chicago, IL). One way analysis of variance (ANOVA) was performed to compare means of primary $\mathrm{N}$ balance data and model parameters for each diet and balance period. To verify the variance homogeneity and identification of significant differences $(p \leq 0.05)$ the Games-Howell and Tukey tests were applied.

\section{Results}

\subsection{N Balance Data}

In the starter period (Table 3), significant differences $(p<0.05)$ between dietary treatments were not observed. Accordingly, mean body weight (BW), dry matter intake (DMI), nitrogen intake (NI), nitrogen excretion (NEX) and nitrogen deposition (ND) data were not dependent on the diet under study. The grower period (Table 4) 
yielded similar observations. The decline of NEX in birds fed diets 3 and 5 was attributed only to the lower NI.

\subsection{Model Parameters and IAAR}

According to the observed ND data, model parameter $b$ indicated no significant response on dietary protein quality during the starter period (Table 5). The yielded Met efficiency data $\left(b c_{\mathrm{Met}}{ }^{-1}\right)$ were not significantly improved both by increased Cys supply and supplementation of BET (diet 4). As expected, the excessive Met supply in

Table 3. Summarized results of the $\mathrm{N}$ balance experiments during starter period $(\mathrm{d} 10-20)^{1}$.

\begin{tabular}{|c|c|c|c|c|c|}
\hline Diet & 1 & 2 & 3 & 4 & 5 \\
\hline Cys:Met & $85: 100$ & 95:100 & $105: 100$ & $105: 100^{2}$ & $95: 100^{3}$ \\
\hline $\mathrm{n}$ & 24 & 24 & 24 & 24 & 24 \\
\hline $\mathrm{BW}(\mathrm{g})$ & $489 \pm 29$ & $494 \pm 29$ & $498 \pm 28$ & $518 \pm 29$ & $506 \pm 28$ \\
\hline DMI (g/d) & $63.1 \pm 2.4$ & $63.3 \pm 2.4$ & $63.9 \pm 2.3$ & $65.8 \pm 2.3$ & $65.6 \pm 2.2$ \\
\hline $\mathrm{NI}$ & $3950 \pm 34$ & $3937 \pm 44$ & $3964 \pm 47$ & $3973 \pm 40$ & $4010 \pm 54$ \\
\hline NEX & $1325 \pm 35$ & $1325 \pm 20$ & $1362 \pm 42$ & $1354 \pm 38$ & $1359 \pm 53$ \\
\hline ND & $2625 \pm 37$ & $2612 \pm 39$ & $2602 \pm 22$ & $2619 \pm 30$ & $2651 \pm 28$ \\
\hline
\end{tabular}

$\mathrm{BW}=$ Body weight, DMI = Dry matter intake, $\mathrm{NI}=\mathrm{N}$ intake $\left(\mathrm{mg} / \mathrm{BW}_{\mathrm{kg}}{ }^{0.67}\right), \mathrm{NEX}=\mathrm{N}$ excretion $\left(\mathrm{mg} / \mathrm{BW}_{\mathrm{kg}}{ }^{0.67}\right), \mathrm{ND}=\mathrm{N}$ deposition $(\mathrm{NI}-\mathrm{NEX})$ $\left(\mathrm{mg} / \mathrm{BW}_{\mathrm{kg}}{ }^{0.67}\right)$; ${ }^{1}$ Mean \pm standard error of mean; ${ }^{2}$ plus betaine; ${ }^{3}$ without supplemented L-lysine·HCl (Lys limiting diet); No significant difference between mean values was observed.

Table 4. Summarized results of the $\mathrm{N}$ balance experiments during grower period (d25 - 35) ${ }^{1}$.

\begin{tabular}{|c|c|c|c|c|c|}
\hline Diet & 1 & 2 & 3 & 4 & 5 \\
\hline Cys:Met & $85: 100$ & 95:100 & $105: 100$ & $105: 100^{2}$ & $95: 100^{3}$ \\
\hline $\mathrm{n}$ & $22^{4}$ & 24 & $23^{4}$ & 24 & 24 \\
\hline BW (g) & $1532 \pm 47$ & $1579 \pm 45$ & $1599 \pm 50$ & $1605 \pm 49$ & $1640 \pm 49$ \\
\hline DMI (g/d) & $128.4 \pm 3.3$ & $129.8 \pm 2.7$ & $124.3 \pm 3.5$ & $129.6 \pm 3.1$ & $129.9 \pm 2.9$ \\
\hline NI & $3399 \pm 49$ & $3375 \pm 43$ & $3223 \pm 83$ & $3342 \pm 50$ & $3282 \pm 43$ \\
\hline NEX & $1366^{\mathrm{a}} \pm 15$ & $1331^{\mathrm{ab}} \pm 23$ & $1174^{\mathrm{c}} \pm 37$ & $1243^{b c} \pm 30$ & $1221^{\mathrm{c}} \pm 24$ \\
\hline ND & $2033 \pm 42$ & $2044 \pm 42$ & $2049 \pm 53$ & $2099 \pm 33$ & $2061 \pm 28$ \\
\hline
\end{tabular}

$\mathrm{BW}=$ Body weight, DMI = Dry matter intake, $\mathrm{NI}=\mathrm{N}$ intake $\left(\mathrm{mg} / \mathrm{BW}_{\mathrm{kg}}{ }^{0.67}\right), \mathrm{NEX}=\mathrm{N}$ excretion $\left(\mathrm{mg} / \mathrm{BW}_{\mathrm{kg}}{ }^{0.67}\right), \mathrm{ND}=\mathrm{N}$ deposition $(\mathrm{NI}-\mathrm{NEX})$ $\left(\mathrm{mg} / \mathrm{BW}_{\mathrm{kg}}{ }^{0.67}\right) ;{ }^{1}$ Mean \pm standard error of mean; ${ }^{2}$ plus betaine; ${ }^{3}$ without supplemented L-lysine·HCl (Lys limiting diet); ${ }^{4}$ one resp. two birds excluded due to refusing feed intake; ${ }^{\text {abc }}$ Mean values with different superscript letters are significantly different $(p<0.05)$.

Table 5. Summarized results of model parameters for starter and grower period ${ }^{1}$.

\begin{tabular}{|c|c|c|c|c|c|}
\hline $\begin{array}{c}\text { Diet } \\
\text { Cys:Met }\end{array}$ & $\begin{array}{c}1 \\
85: 100\end{array}$ & $\begin{array}{c}2 \\
95: 100\end{array}$ & $\begin{array}{c}3 \\
105: 100\end{array}$ & $\begin{array}{c}4 \\
105: 100^{2}\end{array}$ & $\begin{array}{c}5 \\
95: 100^{3}\end{array}$ \\
\hline$c_{\text {Met }}^{4}(\mathrm{~g} / 16 \mathrm{gN})$ & 1.72 & 1.72 & 1.71 & 1.71 & 2.34 \\
\hline$c_{\mathrm{Lys}}^{5}(\mathrm{~g} / 16 \mathrm{gN})$ & 6.15 & 6.14 & 6.14 & 6.14 & 5.18 \\
\hline \multicolumn{6}{|l|}{ Starter period $(d 10-20)$} \\
\hline Protein quality $(b)$ & $337 \pm 8$ & $335 \pm 6$ & $329 \pm 5$ & $333 \pm 7$ & $338 \pm 7$ \\
\hline Met efficiency $\left(b c_{\mathrm{Met}^{-1}}{ }^{-1}\right)$ & $196^{\mathrm{a}} \pm 4$ & $195^{\mathrm{a}} \pm 4$ & $192^{\mathrm{a}} \pm 3$ & $194^{\mathrm{a}} \pm 4$ & $144^{\mathrm{b}} \pm 3$ \\
\hline Lys efficiency $\left(b c_{\mathrm{Lys}}{ }^{-1}\right)$ & $55^{\mathrm{b}} \pm 1$ & $54^{\mathrm{b}} \pm 1$ & $54^{\mathrm{b}} \pm 1$ & $54^{\mathrm{b}} \pm 1$ & $65^{\mathrm{a}} \pm 1$ \\
\hline IAAR (Met:Lys) ${ }^{6}$ & 33.2 & 33.5 & 34.0 & 33.6 & \\
\hline \multicolumn{6}{|l|}{ Grower period (d25 - 35) } \\
\hline Protein quality $(b)$ & $425 \pm 12$ & $437 \pm 16$ & $461 \pm 14$ & $462 \pm 12$ & $449 \pm 8$ \\
\hline Met efficiency $\left(b c_{\mathrm{Met}^{-1}}{ }^{-1}\right)$ & $248^{\mathrm{a}} \pm 7$ & $255^{\mathrm{a}} \pm 9$ & $269^{\mathrm{a}} \pm 8$ & $270^{\mathrm{a}} \pm 7$ & $192^{\mathrm{b}} \pm 4$ \\
\hline Lys efficiency $\left(b c_{\text {Lys }}{ }^{-1}\right)$ & $69^{\mathrm{b}} \pm 2$ & $71^{b} \pm 3$ & $75^{\mathrm{b}} \pm 2$ & $75^{\mathrm{b}} \pm 2$ & $87^{\mathrm{a}} \pm 2$ \\
\hline IAAR (Met:Lys) ${ }^{6}$ & 35.0 & 34.0 & 32.2 & 32.2 & \\
\hline
\end{tabular}

${ }^{1}$ Mean \pm standard error of mean; ${ }^{2}$ plus betaine; ${ }^{3}$ without supplemented L-lysine $\mathrm{HCl}$ (Lys limiting diet); ${ }^{4}$ dietary methionine concentration; ${ }^{5}$ dietary lysine concentration; ${ }^{6}$ percent of methionine in relation to lysine (Lys = 100) calculated according to Equation (4); ${ }^{\text {abc }}$ Mean values with different superscript letters within lines are significantly different $(p<0.05)$. 
the Lys limiting diet 5 (Table 2) led to a significant decline $(p<0.05)$ of Met efficiency. Accordingly, the Lys efficiency in diet 5 was significantly higher and indicating the limiting position of Lys which was needed as reference AA for assessing the IAAR. Based on AA efficiency data, during starter period the optimal Met to Lys ratio was observed between 33and 34 percent of the Lys supply.

In the grower period, diets 1 - 4 also yielded no significant effect $(p>0.05)$ on dietary protein quality (model parameter $b$ ). However, a trend of increasing dietary protein quality was indicated when the dietary Cys supply was elevated. This tendency gives some support to a higher demand for Cys during grower period. Accordingly, the dietary Met efficiency also tended to be improved with increasing Cys supply. Supplemented BET yielded no additional effect both on protein quality and Met efficiency. As expected, the Lys efficiency with diet 5 was significantly improved $(p<0.05)$ indicating the limiting position of Lys supply when crystalline Lys was deleted from the diet (Table 1). The derived optimal Met to Lys ratio corresponding to the grower diets 1 - 4 was $35,34,32$ and 32 to 100 , respectively.

\section{Discussion}

According to principles of the AA dilution technique, the dietary AA efficiency of the individual LAA can be directly measured by response on observed $\mathrm{N}$ balance data, when introduced into physiological based modeling procedures. In addition, the model parameters of observed dietary AA efficiency are validated to be used for assessing optimal dietary AA ratios [7]-[9] [31] by application of equation (4). Unfortunately, literature data provide no validated information about the extent to which Cys should contribute to the total SAA supply in growing chicken depending on age. Based on current applications, the results during the starter period indicate no pronounced effect on protein utilization when the Cys to Met ratio in Met limiting diets varied between 85 and 105 to 100 (corresponding to 46 and 51 percent Cys related to total SAA supply). This observation was in line with results of Liebert et al. [25].

Experiments with L-Cys supplementations to SAA limiting starter diets (Cys to Met ratio equal or slightly higher) failed to respond significantly both on growth data and feed efficiency [35]. Moran [36] observed no effect on chicken growth $(0-14 \mathrm{~d})$ in two experiments with corn-soybean meal diets when the dietary Cys supply ranged between 40 and 51 percent of the total SAA supply. However, feed efficiency was significantly improved at the highest level of Cys supply. Similar results were reported by Beck et al. [37] following Cys supplementations to starter diets up to $47 \%$ of the total SAA supply. In contrast, several reports [24] [38]-[40] demonstrated negative effects both on growth data and feed efficiency during week 1 to 3 posthatch when Cys contributed more than $60 \%$ and up to $77 \%$ of total SAA supply. Depressed feed intake was a primary factor for these observations [24]. Markedly reduced feed intake was also reported when Cys free or low Cys diets were fed during second and third week of age [41] [42].

For starter chicken, the optimal Cys contribution to SAA supply depending on diet composition (purified AA or practical type diets) and reference criterion (BW gain, feed efficiency or body protein deposition) was found to be between $48 \%$ and $58 \%$ [38], at $54 \%$ [43] or between $56 \%$ and $60 \%$ [44].

In agreement with early research of Graber et al. [44] and Moran [36], the effect of an elevated Cys to Met ratio was more obvious in the grower period of our current study. Our previous experiment [25] yielded a higher Met efficiency following Cys supplementation indicating a higher need for Cys due to increased feather plumage of older birds. The synthesis of keratoid tissues, the major feather protein, elevates the relative importance of Cys within the SAA supply [36] [45]-[47]. However, each increment in Cys supply demands an equal increment of Met in the diet [48]. Based on observations of Graber et al. [44] with crystalline AA diets, the Cys requirement of chicken increases from $0.34 \%$ to $0.44 \%$ of the diet during the $2^{\text {nd }}$ and $8^{\text {th }}$ weeks of life.

Accordingly, the relative contribution of Cys to the total SAA increased from $56 \%$ to $67 \%$ when BW gain or from $60 \%$ to $70 \%$ when gain/feed ratio were used as reference criterions. Adding Cys up to $55 \%$ of total SAA in finishing diets (33 - $44 \mathrm{~d}$ ) increased the quantity of feathers as compared to diets with $42 \%$ or $49 \%$ Cys of total SAA [36]. Between 4 to 6 weeks post hatching, on digestible AA basis Cys may contribute up to 52\% of the total SAA supply [18]. Kalinowski et al. [47] concluded only $44 \%$ and $47 \%$ Cys as adequate proportion of the SAA need for slow- and fast-feathering 3 to 6 weeks old broilers. In contrast, Wheeler and Latshaw [43] mentioned that Cys at $38 \%$ to $43 \%$ of the SAA is adequate in the grower period (21 - 42 d), indicating a lower replacement value for Met as compared to the starter period (54\%).

BET supplementation to Cys and choline enriched diet 4 did not respond on protein quality and Met efficiency. This observation is in line with several reports [49]-[55]. They observed no significant effect of added 
BET on growth of chicken when supplemented to marginally Met deficient and methyl donor-adequate diets, even when dietary choline supply was reduced [56] [57].

Currently observed Met efficiency data provided an IAAR for Met to Lys between 32 and 35 to 100 in diets for both of the age periods (Table 5). An averaged dietary Met proportion of 34\% as compared to Lys (100\%) for growing chicken is concluded from experimental data of diets $1-3$. This Met to Lys ratio is lower than the mean ratio (40 \pm 4 to 100) as derived from literature data and experimental results [8] [11] [16]. In previous studies with semi-synthetic diets, an optimal Met to Lys ratio of 36 to 100 was concluded for both age periods [14] [17]. Accordingly, Met to Lys ratios between 35:100 and 38:100 were reported to be adequate for maximal growth performance during both age periods [15] [23] [58]. In contrast, also higher recommendations of dietary Met to Lys ratios from 47 - 48 to 100 for 3 to 16 days old chicken are reported [59]. Furthermore, NRC [22] recommends a Met to Lys ratio of 45:100 for the starter, but only 38:100 for the grower chicken.

Several factors may impact on the observed disharmony between both the recommended dietary Cys to Met and Met to Lys ratio for growing chicken. According to Baker et al. [18], Kalinowski et al. [46] and Baker [60], a series of factors may overlay evaluating of the ideal ratios between these AAs. Especially, the applied experimental approach must be taken into account. Coon [15] observed different IAARs dependent on reference criterion and method of regression analysis. Broken line and exponential regression analysis yielded Met to Lys ratio of 36 to 100 both for BW gain and feed efficiency, but uric acid excretion as reference criterion resulted in a ratio of 32 to 100 . Otherwise, a higher Met to Lys ratio (44 to 100) was concluded when polynomial regression analysis utilized nitrogen or AA accretion as reference criterion. Application of physiological based new procedures like "Goettingen approach" might contribute to more validated recommendations in the future. However, the variation of dietary AA efficiency resulting from varying ingredient composition of experimental diets remains an important factor of influence, even if sophisticated approaches are applied.

\section{Conclusions}

In conclusion, the reported studies based on data evaluation by "Goettingen approach" demonstrate, that elevated Cys supply between 85 and 105 percent of Met supply failed to improve both dietary protein quality and Met efficiency in starter diets for meat type chicken. In grower diets, a trend of improved protein quality and Met efficiency was observed, indicating higher nutritional importance of Cys supply in older chicken. The optimal dietary ratio of Met to Lys of 34 to 100 as concluded for both of the age periods ranks within the lower ratios reported in the literature. Supplemented betaine yielded no additional effect of the observed parameters of protein quality and AA efficiency, respectively.

The high variation of recommendations to meet the SAA needs in meat type chicken requires more investigations, but also more standardized experimental conditions for more validated conclusions.

\section{References}

[1] Wijtten, P.J.A., Lemme, A. and Langhout, D.J. (2004) Effects of Different Dietary Ideal Protein Levels on Male and Female Broiler Performance during Different Phases of Life: Single Phase Effects, Carry over Effects, and Interactions between Phases. Poultry Science, 83, 2005-2015. http://dx.doi.org/10.1093/ps/83.12.2005

[2] Kidd, M.T., Corzo, A., Hoehler, D., Miller, E.R. and Dozier III, W.A. (2005) Broiler Responsiveness (Ross $\times 708$ ) to Diets Varying in Amino Acid Density. Poultry Science, 84, 1389-1396. http://dx.doi.org/10.1093/ps/84.9.1389

[3] Taherkhani, R., Shivazad, M., Zaghari, M. and Shahneh, A. (2008) Comparison of Different Ideal Amino Acid Ratios in Male and Female Broiler Chickens of 21 to 42 Days of Age. The Journal of Poultry Science, 45, 15-19. http://dx.doi.org/10.2141/jpsa.45.15

[4] Coneglian, J.L.B., Vieira, S.L., Berres, J. and de Freitas, D.M. (2010) Responses of Fast and Slow Growth Broilers Fed All Vegetable Diets with Variable Ideal Protein Profiles. Revista Brasileira de Zootecnia, 39, 327-334. http://dx.doi.org/10.1590/S1516-35982010000200015

[5] Corzo, A. (2012) Determination of the Arginine, Tryptophan, and Glycine Ideal-Protein Ratios in High-Yield Broiler Chicks. The Journal of Applied Poultry Research, 21, 79-87. http://dx.doi.org/10.3382/japr.2011-00362

[6] Vieira, S.L., Taschetto, D., Angel, C.R., Favero, A., Mascharello, N.C. and Nogueira, E.T. (2012) Performance and Carcass Characteristics of Cobb $\times$ Cobb 500 Slow-Feathering Male Broilers Fed on Dietary Programs Having Stepwise Increases in Ideal Protein Density. The Journal of Applied Poultry Research, 21, 797-805. http://dx.doi.org/10.3382/japr.2012-00523 
[7] Pastor, A., Wecke, C. and Liebert, F. (2013) Assessing the Age-Dependent Optimal Dietary Branched-Chain Amino Acid Ratio in Growing Chicken by Application of a Nonlinear Modeling Procedure. Poultry Science, 92, 3184-3195. http://dx.doi.org/10.3382/ps.2013-03340

[8] Wecke, C. and Liebert, F. (2013) Improving the Reliability of Optimal In-Feed Amino Acid Ratios Based on Individual Amino Acid Efficiency Data from N Balance Studies in Growing Chicken. Animals, 3, 558-573. http://dx.doi.org/10.3390/ani3030558

[9] Samadi and Liebert, F. (2008) Modelling the Optimal Lysine to Threonine Ratio in Growing Chickens Depending on Age and Efficiency of Dietary Amino Acid Utilisation. British Poultry Science, 49, 45-54. http://dx.doi.org/10.1080/00071660701821667

[10] Conde-Aguilera, J.A., Cobo-Ortega, C., Tesseraud, S., Lessire, M., Mercier, Y. and van Milgen, J. (2013) Changes in Body Composition in Broilers by a Sulfur Amino Acid Deficiency during Growth. Poultry Science, 92, 1266-1275. http://dx.doi.org/10.3382/ps.2012-02796

[11] Wecke, C., Pastor, A. and Liebert, F. (2013) Ideal In-Feed Amino Acid Ratios for Growing Broiler Chicken Based on Individual Amino Acid Efficiency Data Derived from N Balance Studies. Proceedings of the 19th European Symposium on Poultry Nutrition, Potsdam, 26-29 August 2013, File 180 PPII-15, 1-5.

[12] D’Mello, J.P.F. (2003) Responses of Growing Poultry to Amino Acids. In: D’Mello, J.P.F., Ed., Amino Acids in Animal Nutrition, 2nd Edition, CAB International, Wallingford, Oxon, 237-263. http://dx.doi.org/10.1079/9780851996547.0237

[13] Lewis, A.J. (2003) Methionine-Cystine Relationships in Pig Nutrition. In: D’Mello, J.P.F., Ed., Amino Acids in Animal Nutrition, 2nd Edition, CAB International, Wallingford, Oxon, 143-155. http://dx.doi.org/10.1079/9780851996547.0143

[14] Baker, D.H. (2003) Ideal amino acid patterns for broiler chicks. In: D’Mello, J.P.F., Ed., Amino Acids in Animal Nutrition, 2nd Edition, CAB International, Wallingford, Oxon, 223-235. http://dx.doi.org/10.1079/9780851996547.0223

[15] Coon, C. (2004) The Ideal Amino Acid Requirements and Profile for Broilers, Layers, and Broiler Breeders. Technical Information of American Soybean Association, FE 153, 1-43.

[16] Rostagno, H.S., Ed. (2005) Brazilian Tables for Poultry and Swine. Composition of Feedstuffs and Nutritional Requirements. 2nd Edition, Universidade Federal de Viçosa, Vicosa.

[17] Baker, D.H. and Han, Y. (1994) Ideal Amino Acid Profile for Chicks during the First Three Weeks Posthatching. Poultry Science, 73, 1441-1447. http://dx.doi.org/10.1079/9780851996547.0223

[18] Baker, D.H., Fernandez, S.R., Webel, D.M. and Parsons, C.M. (1996) Sulfur Amino Acid Requirement and Cystine Replacement Value of Broiler Chicks during the Period Three to Six Weeks Posthatching. Poultry Science, 75, 737742. http://dx.doi.org/10.3382/ps.0750737

[19] Mack, S., Bercovici, D., de Groote, G., Leclercq, B., Lippens, M., Pack, M., Schutte, J.B. and van Cauwenberghe, S. (1999) Ideal Amino Acid Profile and Dietary Lysine Specification for Broiler Chickens of 20 to 40 Days of Age. British Poultry Science, 40, 257-265. http://dx.doi.org/10.1080/00071669987683

[20] Vieira, S.L., Lemme, A., Goldenberg, D.B. and Brugalli, I. (2004) Responses of Growing Broilers to Diets with Increased Sulfur Amino Acids to Lysine Ratios at Two Dietary Protein Levels. Poultry Science, 83, 1307-1313. http://dx.doi.org/10.1093/ps/83.8.1307

[21] Madsen, T.G., Hangoor, E., Wijtten, P.J.A., Sparla, J.K.W.M. and Lemme, A. (2010) Optimal Sulphur Amino Acid to Lysine Ratio in Grower Phase in Ross 308 Broilers. Proceedings of the 21st Annual Australian Poultry Science Symposium, Sydney, 1-3 February 2010, 90-93.

[22] NRC, National Research Council (1994) Nutrient Requirements of Poultry. 9th Edition, National Academy Press, Washigton DC.

[23] GRRS, German Recommendations for Requirement Standards (Ausschuss für Bedarfsnormen der Gesellschaft für Ernährungsphysiologie) (1999) Empfehlungen zur Energie- und Nährstoffversorgung der Legehennen und Masthühner (Broiler). DLG-Verlag, Frankfurt am Main.

[24] Dilger, R.N. and Baker, D.H. (2007) DL-Methionine Is as Efficacious as L-Methionine, but Modest L-Cystine Excess Are Anorexigenic in Sulfur Amino Acid-Deficient Purified and Practical-Type Diets Fed to Chicks. Poultry Science, 86, 2367-2374. http://dx.doi.org/10.3382/ps.2007-00203

[25] Liebert, F., Farke, J. and Wecke, C. (2010) Modelling Methionine Requirements in Growing Chicken by Using the Dietary Methionine Efficiency. Proceedings of the 3rd EAAP International Symposium on Energy and Protein Metabolism and Nutrition, Parma, 6-10 September 2010, 625-626.

[26] Virtanen, E. and Rosi, L. (1995) Effects of Betaine on Methionine Requirement of Broilers under Various Environmental Conditions. Proceedings of the Australian Poultry Science Symposium, Sydney, 31 January-1 February 1995, 88-92. 
[27] Attia, Y., Hassan, R., Shehatta, M. and Abd El-Hady Slawa, B. (2005) Growth, Carcass Quality and Serum Constituents of Slow Growing Chicks as Affected by Betaine Addition to Diets Containing 2. Different Levels of Methionine. International Journal of Poultry Science, 4, 856-865. http://dx.doi.org/10.3923/ijps.2005.856.865

[28] El-Husseiny, O.M., Abo-El-Ella, M.A., Abd-Elsamee, M.O. and Abd-Elfattah, M.M. (2007) Response of Broilers Performance to Dietary Betaine and Folic Acid at Different Methionine Levels. International Journal of Poultry Science, 6, 515-523. http://dx.doi.org/10.3923/ijps.2007.515.523

[29] Sun, H., Yang, W.R., Yang, Z.B., Wang, Y., Jiang, S.Z. and Zhang, G.G. (2008) Effects of Betaine Supplementation to Methionine Deficient Diet on Growth Performance and Carcass Characteristics of Broilers. American Journal of Animal and Veterinary Sciences, 3, 78-84. http://dx.doi.org/10.3844/ajavsp.2008.78.84

[30] Rama Rao, S.V., Raju, M.V.L.N., Panda, A.K., Saharia, P. and Shyam Sunder, G. (2011) Effect of Supplementing Betaine on Performance, Carcass Traits and Immune Responses in Broiler Chicken Fed Diets Containing Different Concentrations of Methionine. Asian-Australian Journal of Animal Science, 24, 662-669. http://dx.doi.org/10.5713/ajas.2011.10286

[31] Liebert, F. (2015) Basics and Applications of an Exponential Nitrogen Utilization Model (“Goettingen Approach”) for Assessing Amino Acid Requirements in Growing Pigs and Meat Type Chickens Based on Dietary Amino Acid Efficiency. In: Sakomura, N.K., Gous, R., Kyriazakis, I. and Hauschild, L., Eds., Nutritional Modelling for Pigs and Poultry, CABI Publication, Wallingford, Oxfordshire, 73-87.

[32] WPSA (1984) The Prediction of Apparent Metabolizable Energy Values for Poultry in Compound Feeds. World's Poultry Science Journal, 40, 181-182.

[33] Naumann, C. and Bassler, R. (1997) Die chemischen Untersuchungen von Futtermitteln. Methodenbuch, Volume III, VDLUFA-Verlag, Darmstadt.

[34] Liebert, F. (2008) Modelling of Protein Metabolism Yields Amino Acid Requirements Dependent on Dietary Amino Acid Efficiency, Growth Response, Genotype and Age of Growing Chicken. Avian Biology Research, 1, 101-110. http://dx.doi.org/10.3184/175815508X388074

[35] Pesti, G.M., Harper, A.E. and Sunde, M.L. (1979) Sulfur Amino Acid and Methyl Donor Status of Corn-Soy Diets Fed to Starting Broiler Chicks and Turkey Poults. Poultry Science, 58, 1541-1547. http://dx.doi.org/10.3382/ps.0581541

[36] Moran, E.T. (1981) Cystine Requirement of Feather-Sexed Broiler Chickens with Sex and Age. Poultry Science, 60, 1056-1061. http://dx.doi.org/10.3382/ps.0601056

[37] Beck, C.R., Harms, R.H. and Russell, G.B. (1998) Is the Cystine Content of the Diet of Concern for Broilers from 0 to 21 Days of Age? The Journal of Applied Poultry Research, 7, 233-238. http://dx.doi.org/10.1093/japr/7.3.233

[38] Sasse, C.E. and Baker, D.H. (1974) Sulfur Utilizattion by the Chick with Emphasis on the Effect of Inorganic Sulfate on the Cystine-Methionine Interrelationship. The Journal of Nutrition, 104, 244-251

[39] Featherston, W.R. and Rogler, J.C. (1978) Methionine-Cystine Interrelations in Chicks Fed Diets Containing Suboptimal Levels of Methionine. The Journal of Nutrition, 108, 1954-1958.

[40] Sell, D.R., Featherston, W.R. and Rogler, J.C. (1980) Methionine-Cystine Interrelationships in Chicks and Rats Fed Diets Containing Suboptimal Levels of Methionine. Poultry Science, 59, 1878-1884. http://dx.doi.org/10.3382/ps.0591878

[41] Graber, G. and Baker, D.H. (1971) Sulfur Amino Acid Nutrition of the Growing Chick: Quantitative Aspects Concerning the Efficacy of Dietary Methionine, Cysteine and Cystin. Journal of Animal Science, 33, 1005-1011.

[42] Ohta, Y. and Ishibashi, T. (1994) Dietary Levels and Ratio of Methionine and Cystine for Maximum Performance of Broilers. Japanese Poultry Science, 31, 369-380. http://dx.doi.org/10.2141/jpsa.31.369

[43] Wheeler, K.B. and Latshaw, J.D. (1981) Sulfur Amino Acid Requirements and Interactions in Broilers during Two Growth Periods. Poultry Science, 60, 228-236. http://dx.doi.org/10.3382/ps.0600228

[44] Graber, G., Scott, H.M. and Baker, D.H. (1971) Sulfur Amino Acid Nutrition of the Growing Chick: Effect of Age on the Capacity of Cystine to Spare Dietary Methionine. Poultry Science, 50, 1450-1455. http://dx.doi.org/10.3382/ps.0501450

[45] Stilborn, H.L., Moran, E.T., Gous, R.M. and Harrison, M.D. (1997) Effect of Age on Feather Amino Acid Content in Two Broiler Strain Crosses and Sexes. The Journal of Applied Poultry Research, 6, 205-209. http://dx.doi.org/10.1093/japr/6.2.205

[46] Kalinowski, A., Moran Jr., E.T. and Wyatt, C.L. (2003) Methionine and Cystine Requirements of Slow- and FastFeathering Male Broilers from Zero to Three Weeks of Age. Poultry Science, 82, 1423-1427. http://dx.doi.org/10.1093/ps/82.9.1423

[47] Kalinowski, A., Moran Jr., E.T. and Wyatt, C.L. (2003) Methionine and Cystine Requirements of Slow- and FastFeathering Broiler Males from Three to Six Weeks of Age. Poultry Science, 82, 1428-1437. http://dx.doi.org/10.1093/ps/82.9.1428 
[48] Baker, D.H. (2009) Advances in Protein-Amino Acid Nutrition of Poultry. Amino Acids, 37, 29-41. http://dx.doi.org/10.1007/s00726-008-0198-3

[49] Rostagno, H.S. and Pack, M. (1996) Can Betaine Replace Supplemental DL-Methionine in Broiler Diets? The Journal of Applied Poultry Research, 5, 150-154. http://dx.doi.org/10.1093/japr/5.2.150

[50] Schutte, J.B., de Jong, J., Smink, W. and Pack, M. (1997) Replacement Value of Betaine for DL-Methionine in Male Broiler Chicks. Poultry Science, 76, 321-325. http://dx.doi.org/10.1093/ps/76.2.321

[51] Esteve-Garcia, E. and Mack, S. (2000) The Effect of DL-Methionine and Betaine on Growth Performance and Carcass Characteristics in Broilers. Animal Feed Science and Technology, 87, 85-93. http://dx.doi.org/10.1016/S0377-8401(00)00174-7

[52] McDevitt, R.M., Mack, S. and Wallis, I.R. (2000) Can Betaine Partially Replace or Enhance the Effect of Methionine by Improving Broiler Growth and Carcase Characteristics? British Poultry Science, 41, 473-480. http://dx.doi.org/10.1080/713654957

[53] Kermanshahi, H. (2001) Betaine Replacement for DL-Methionine in the Performance and Carcass Characteristics of Broiler Chicks. Journal of Agricultural Science and Technology, 3, 273-279.

[54] Baghaei, M., Ashayerizadeh, A., Eslami, M., Bojarpour, M., Roshanfekr, H. and Mirzadeh, K.H. (2009) Betaine (Betafin $\left.^{B}\right)$ Replacement for Methionine in Diet on Growth Performance and Carcass Characteristics of Broiler Chickens. Research Journal of Biological Sciences, 4, 1037-1040.

[55] Lukić, M., Jokić, Ž., Petričević, V., Pavlovski, Z., Škrbić, Z. and Stojanović, L. (2012) The Effect of Full Substitution of Supplemental Methionine with Betaine in Broiler Nutrition on Production and Slaughter Results. Biotechnology in Animal Husbandry, 28, 361-368. http://dx.doi.org/10.2298/BAH1202361L

[56] Creswell, D. (2013) Comparison of Anhydrous and Hydrochloride Forms of Betaine on Broiler Performance. Proceedings of the 24th Annual Australian Poultry Science Symposium, Sydney, 17 February 2013, 154-157.

[57] Sakomura, N.K., Barbosa, N.A.A., Longo, F.A., da Silva, E.P., Bonato, M.A. and Fernandes, J.B.K. (2013) Effect of Dietary Betaine Supplementation on the Performance, Carcass Yield, and Intestinal Morphometrics of Broilers Submitted to Heat Stress. Revista Brasileira de Ciencia Avicola, 15, 105-112. http://dx.doi.org/10.1590/S1516-635X2013000200005

[58] Emmert, J.L. and Baker, D.H. (1997) Use of the Ideal Protein Concept for Precision Formulation of Amino Acid Levels in Broiler Diets. The Journal of Applied Poultry Research, 6, 462-470. http://dx.doi.org/10.1093/japr/6.4.462

[59] Mehri, M., Davarpanah, A.A. and Mirzaei, H.R. (2012) Estimation of Ideal Ratios of Methionine and Threonine to Lysine in Starting Broiler Chicks Using Response Surface Methodology. Poultry Science, 91, 771-777. http://dx.doi.org/10.3382/ps.2011-01818

[60] Baker, D.H. (2006) Comparative Species Utilization and Toxicity of Sulfur Amino Acids. The Journal of Nutrition, 136, 1670S-1675S. 